\title{
The Implementation of Lesson Study Programme for Developing Professionalism in Teaching Profession
}

\author{
Jimmi Copriady ${ }^{1}$ \\ ${ }^{1}$ Faculty of Education, University of Riau, Indonesia \\ Correspondence: Jimmi Copriady, Faculty of Education, University of Riau, Indonesia. E-mail: \\ jimmiputra@yahoo.co.id
}

Received: August 1, 2013 Accepted: August 16, 2013 Online Published: August 30, 2013

doi:10.5539/ass.v9n12p176 URL: http://dx.doi.org/10.5539/ass.v9n12p176

\begin{abstract}
The aim of this study was to identify teachers view in relation with the implementation of Lesson Study, a program of professional development for teachers. An action research was conducted by using a questionnaire to gauge teachers' acceptance of Lesson Study. The sample consisted of 40 teachers from High Schools (SMA) in Indonesia were recruited for this study. The implementation of Lesson Study involves four stages: planning, micro teaching, discussion and reflection. For the pilot study, Cronbach's Alpha reliability for the items ranges from 0.82 to 0.93 . The results showed that Chemistry and English teachers' acceptance of Lesson Study program is high compared with the teachers of other subjects which is moderate. For the aspects of differences in the acceptance of Lesson Study program based on different fields, there was no significant difference between the teachers of Science and Social Science. The overall results showed that acceptance and understanding about Lesson Study program was still at a moderate level. The study also found that professional development program through Lesson Study program enables subject teachers to be monitored each other through the concept of collaborative work in improving pedagogical skills. The results showed that the expansion of the teaching process through Lesson Study program can be used as a program for teachers' professional development. There are significant differences among the perspectives of teachers teaching different subjects about Lesson Study. However, all teachers showed good perception in relation to the implementation of Lesson Study. It is proposed that Lesson Study is used as an alternative approach to solve the problems that the teachers are facing in the implementation of teaching and learning.
\end{abstract}

Keywords: lesson study, teacher appreciation, professionalism, teaching and learning

\section{Introduction}

Teacher's roles and leadership in the instructional process is the deciding factor for the effectiveness of teaching and learning in the classroom. As a result, teachers' skills and pedagogical skills should be evaluated and improved in order to achieve the quality and standards that have been set out so that teacher's instructions would be more effective and effective teaching could be established.

Trained teachers who are recruited to fill the vacancies in school should be willing to develop their skills from time to time as the training they received in teacher training is not enough (Margono, 1999). Mulyati Arifin (1995) highlighted the same concern that teaching can be a catalyst for change. This means that teachers need to be sensitive with all the new changes related to technology, application pedagogy and social skills.

The need for professional development of teachers is very important because when teachers are in school and dealing with students, the reality requires teachers with high competence in accordance with the needs and challenges faced, especially when dealing with students from diverse backgrounds. Orlich et al. (1998) noted that teachers lacking in skills to extend learning materials to students can degrade the quality of teaching. Teachers should not be in a comfort zone by practicing static and routine way of teaching as they may not know how to deal with the changes alone without efforts to reform and improve,

Therefore the assistance from other teachers' in the Subject Panel is needed to study the weaknesses and assess the aspects of improvement to be done. The use of Lesson Study seemed so appropriate and more practical as there is a collaboration of actions to plan, implement instruction, identify weaknesses and then reflect on the processes before implementing changes and improvements. Lesson Study Program is a form of teaching 
innovation which was pioneered in Japan and has left a very positive effect on the quality of education and the quality of teaching, that it also has been implemented by other developed countries such as in the Europe and the United States. Lesson Study Program can be construed as the best way or approach that can be used to enhance teacher professionalism.

\section{Problem Statement}

The effectiveness of In-Service Training (INSET) in developing teachers' professionalism seemed to be less favorable as it is conducted through workshop and the time allocated is inappropriate and inadequate, but mostly the knowledge sharing and discussion sessions do not lead to specific goals in improving the quality of teaching. This is indicated by Amin Senin (2008) who noted INSET as a form of training and workshops to meet requirements for teacher training, but oftentimes the top bottom approach and one-off events is neither effective nor make a significant or actual impact to the advancement of professionalism.

Similar views was also raised by Cheah \& Lim (2010) who asserts that teachers who attend a course are often required to train other teachers when they return to school. On the surface, it seems like a very efficient approach as more and more teachers will be exposed to new theories and pedagogies that have been received by the teacher who are sharing with the hope that it will improve teacher professionalism. However, there is still a gap between the things outlined in the course curriculum and planning at the highest level with the things that are shared and practiced in the classroom (Awang, Jindal-Snape \& Barber, 2013; Awang et al.). This item has brought about a lot of critical discussions about the issues plaguing the teaching and learning of students.

According to Brook \& Brook (1993), educational reform must begin with how students learn and how teachers teach, and not merely looking at the achievement. The same thing is indicated by Podhorsky\& Moore (2006) that educational reform must be filled with the measures and efforts to improve the quality of teaching and learning, not just focusing on planning a class with teacher-proof curriculum. The teachers actually know the problems they are facing in their teaching but not all teachers will be able to solve these problems. This situation requires a discussion forum among teachers to solve their problems which are also the obstacles and challenges to achieve their educational goals at work. This suggests that teachers' professional development must take into account the aspects of teacher competence and pedagogical skills (Abdul Razaq et. Al., 2013; Rhoda et al. 2011) found that there is a close relationship between teacher professionalism with the act of fostering interest in learning among students. This shows that the teachers are central to the effectiveness of teaching and learning.

Sutopo \& Ibrahim (2006) acknowledge that teachers' are being bound to routine tasks and stereotypical approaches in teaching and this causes students to be tired of the approaches and feel as if they are not free to learn. Teachers who are seemingly weak in teaching methods and approaches need a leap of change and training to improve their teaching competencies. Although many proposals have been made at the government level, the studies showed that teachers still have constraints to implement these recommendations (Awang, Jindal-Snape\& Barber, 2013).

Siskandar (2003) also recognizes the need for teachers to get inputs and criticisms to improve their quality of teaching, and one approach that is considered as effective is Lesson Study program. A forum is createdto allow discussions among teachers with the guidance of a professional trainer in education, whether experts from universities, super teacher or professionals from education institutions. Among the activities required are guidance in both lesson planning and implementation of teaching, and these are then discussed to determine the required response. Empirical studies show that active participation in the activities conducted by the teacher are closely related to competent teaching conducted in a creative and thoughtful manner (Awang et. al., 2013). Therefore an alternative approach is more effective to be done in improving the teaching profession, especially in teaching and learning.

\section{Teaching and Learning towards Greater Professionalism Teacher}

Teachers have to effectively deal with the problems in teaching and learning through a willingness to change and make improvements in the teaching process. Recognizing the importance of teacher competency for good teaching and learning, teachers need to recognize the importance of participating in professional development measures from time to time.

The process of teaching and learning is a process that plays an important role in acquiring and disseminating knowledge. Teaching includes all these: actions, reminders and guidelines that are taught. Moore (2004) defines teaching as "the action of a person imparting skills, knowledge, or giving instruction, or the job of a person who teaches". Meanwhile, learning can be defined as a relatively permanent change in behavior which occurs because of gained experience or strengthened practice as defined by Goldstein (2010): "Learning is relatively long 
lasting changes in behavior that are based on past experience".

Actually there are significant differences between the conventional professional development through in-service training compared with a new approach of professional development such as Lesson Study which can be considered as a growth model. With the assumption that teachers have the potential that can be polished and developed, Hayden \& Thompson (2000) list some of his insights on new concepts in teachers' professional development programs, namely: (1) involves organizational development through collaboration (2) staff development through strategic development, (3) staff development which is focused on school, and (4) student needs and learning outcomes. Guskey\& Sparks (1991) emphasizes that teacher professional development is a multidimensional process that contains aspects of training, coaching, culture, practice, modeling, monitoring and evaluation.

\section{Lesson Study Program}

Lesson Study is a staff development program which is introduced by Yoshida (1999) to develop kenkyu jugyo in Japan, which is called the Study of Teaching. As the implementation leaves a significant impact on the quality of teachers and teaching, this concept has been adopted by other countries and has become a model to improve the quality of education and teaching.

Yoshida Lesson Study program, which involves a comprehensive process of planning, observation, analysis and identifying the best teaching approaches in a class, has been made a program for teachers' professional development in Japan. A report released by Zabani Darus (2012) about the status of students' achievement in TIMSS test which involves three countries: the United States, Germany and Japan, has found that teaching and learning of mathematics in Japan was of a very high quality in three aspects, namely:

1) Content of mathematics subject

2) Teacher's strength of delivery through pedagogical skills

3) Student's thinking, teaching and learning

In their book, The Teaching Gap, Stigler \& Hiebert (1999) observe that Japanese teachers' professional development system, the Lesson Study, has contributed to a high performance of mathematics teaching in the classroom. Because of its effectiveness, Lesson Study Group has been started and used in 200 schools in 25 states in the United States and Lesson Study has even been undertaken as a project at the state level in New South Wales, Australia, and among the APEC countries.

\subsection{Teachers Role in the Implementation of Lesson Study}

The teachers have a clear role in the implementation of Lesson Study Program, namely: (1) to think about long-term goals of education - with the aim of enhancing the spirit of learning and appreciation for each other, (2) to consider specific goals of each subject, unit or lesson materials such as historical thinking, the students' level and needs, (3) to study the classroom instruction related to course objectives and students' long-term educational goals (4) to examine impartially how students respond, including in terms of learning, interference and interaction with each other.

During the implementation of Lesson Study, a teacher teaches a group of students by following the teaching steps planned and developed in Lesson Study, while other teachers observe, make comments and provide basic recommendations for improvement of his/her teaching. Lesson Study is not a method of teaching, but initiatives to improve teachers' quality of teaching in a collaborative and sustainable manner by way of planning, implementing, observing and reporting the results of teaching. Lesson Study is a continuous and consistent activity that applies the principles of Total Quality Management (TQM).

\subsection{Importance of Lesson Study}

Lesson Study reviews instructional materials, develops teaching practices, explores ideas to enhance thinking, and helps teachers find solutions to their problems, to understand the topic, and broaden understanding, skills and abilities. Lesson Study has provided a process for collaboration and lesson plans (teaching), and evaluating the success of teaching methods that have been implemented. Slamet Mulyana (2007) argues Lesson Study is a model of educators' professional development through collaborative research and continued teaching based on the college principles and mutual learning to build a learning community.

Lewis (2002) stated: "lesson study is a simple idea. If you want to improve instruction, what could be more obvious than collaborating with fellow teachers to plan, observe, and reflect on lessons? While it may be a simple idea, lesson study is a complex process, supported by collaborative goal setting, careful data collection on student learning, and protocols that enable productive discussion of difficult issues". Due to its benefits, 
according to Isoda (2007), Lesson Study approach has become a form of common practice in school in solving the problems of teaching and learning as well as improving the teachers' skills.

According to Masami Isoda et al. (2007) there are four objectives to be achieved through the implementation of Lesson Study, namely: (1) to obtain a better understanding of how students learn and teachers teach, (2) to obtain specific results to be used by other teachers who do not participate in Lesson Study program, (3) systematically improve the quality of teaching through collaborative inquiry and (4) to develop pedagogical skills through sharing of experience and knowledge with other teachers.

\subsection{Implementation of Lesson Study}

Slamet Mulyana (2007) highlights two ways of implementation of Lesson Study, namely:

1) Lesson Study conducted based on school, which is undertaken by all subject teachers under the supervision of the school principal with the purpose of improving the standards, quality and results of teaching.

2) Lesson Study conducted based on subjects, which includes the study about the process of teaching implemented by a group of teachers of certain subjects, to be practiced in regional, district and provincial levels.

\subsection{Lesson Study Process}

Lesson Study has been applied in a few cities in Indonesia such as Malang, Yogyakarta, and Bandung since 2006 through the scheme called Strengthening In-Service Teacher Training of Mathematics and Science (SISTTEMS) (Susilo, 2007). Lesson Study has been acknowledged as a method for teachers to systematically improve their quality of teaching (Podhorsky \& Moore, 2006).

Lesson Study is a practice in which teachers collaborate to design lesson plans, observe teaching, reflect on teaching and modify or revise and dramatically improve lesson plans. The process involves these five stages of actions:

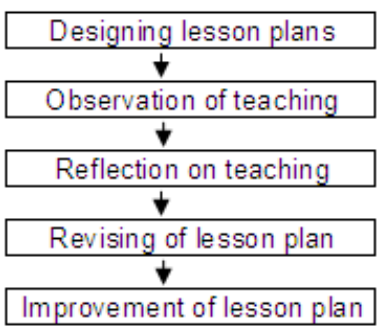

Figure 1. Stages of lesson study program

\subsection{Steps in the Implementation of Lesson Study}

1) Forming Lesson Study Team

Members of assessors for the Lesson Study Program consist of teachers, principals, supervisors, school committee and other parties who are interested in improving the quality of teaching and teaching achievements.

Number of assessors ranges from 4 to 7 people, and they assess and outline improvement for (1) planning, (2) micro teaching, (3) discussion and (4) reflection. It aims to improve the quality of teaching.

2) Arrangement of Time for Lesson Study

The second stage involves restructuring of schedule component provided by the schools to determine the teacher models (representatives of the assessors of Lesson Study) and the target class for the implementation of Lesson Study as well as the individuals who will serve as the evaluator (teacher, school principal, Prefect, School Committee). This stage aims to determine the appropriate class and the time schedule prescribed by the school.

\subsection{Planning and Arrangement of Teaching Materials}

This stage focuses on the provision of teaching resources which are comprehensive instructional design, learning materials, instructional media, stimulus materials and assessment tools. Teaching resources provided by the team or teacher model with adequate qualification 


\section{1) Completing Format, Job Descriptions and Materials for the Implementation of Lesson Study}

This stage involves the technical process of providing the instruments used by the most relevant to teachers, assessors and students covering observation format, check the presence of the observer, the questionnaire for pupils and order of implementation. This format is designed to document the activities of the Lesson Study to be able to do an accurate reflection.

2) Implementing Teaching Activities

This stage involves the implementation of teaching activities, that is the model teacher's teaching activities based on the plan. In this activity, observations are made on the implementation of teaching based on the format provided.

\section{3) Reflecting on the Process}

Reflection on the teaching process involves informal discussions led by a chairman and assisted by a clerk who records in writing. Reflection is started by the model teacher who conveys his/her feelings about before, during and after teaching for the purpose of improving the quality of teaching that follows, as well as self-reflection for the observer. The focus of discussion is to analyze students' behavior, rather than to judge the teacher model.

4) Planning for a Follow-up Action

At this stage, a follow-up action is taken based on the results of the analysis done on reflection activities, which then used as an indicator to identify the strengths and weaknesses found in a teaching process. These findings are further used as a consideration to improve the quality of teaching for the next instructional process.

5) Keeping All the Activities

At this stage, documentation is done by every teacher in a portfolio model. The portfolio components stored includes (1) the adoption of Lesson Study Program (2) Lesson plans and teaching resources, (3) observation sheet for observers, (4) the acquisition of student scores for the adoption of Lesson Study, (5) record the results of discussions and (6) pictures or video footage during the implementation of Lesson Study activities. The recorded activities are meant to be used as evidence and guidance for the use of Lesson Study in learning.

\section{The Purpose of Study}

This study aimed to explore the teachers' perspectives on the use of Lesson Study strategy to improve their quality of teaching. Lesson Study strategy involves collaborative discussions that involve all subject teachers and principals about the strategy. In addition, evaluations were done on planning, teaching methods and reflection on the lessons that had been implemented in Lesson Study strategy within a certain period.

\section{Research Methodology}

Lesson Study was done in the form of action research and workshop for 3 days which involved a sample of 40 teachers: 20 science teachers and 20 social science teachers recruited from 5 high secondary schools (SMA) in Pekanbaru, Indonesia. This study used questionnaires based on Likert scale containing 20 items that tested teachers' acceptance, understanding and knowledge in (1) planning, (2) micro-teaching, (3) discussion and (4) reflection to obtain information about how the teachers were accepting the implementation of Lesson Study

\section{Findings and Discussions}

The study found that teachers reacted positively and tried to adapt to the implementation of Lesson Study and were always motivated to know the feedback from colleagues.

The teachers implemented teaching based on lesson plans provided but they looked quite awkward, uncomfortable and stiff that they needed to adjust to the situation as they were observed by the administrators and colleagues who were there to see the strengths and weaknesses. However, only two teachers were really active in making honest and scholarly comments. The lack of participation did not help much in improving the quality of teaching and learning. However, overall many teachers recognized that the program was more interesting and helpful in enhancing their professionalism compared to the in-service training. According to Santyasa (2009), there are 8 opportunities available to teachers in the implementation of Lesson Study actively: thinking about learning goals; developing learning; deepening knowledge about the subject matter; thinking about long-term goals to achieve; planning collaborative learning; carefully examining the means and process of learning; developing pedagogical knowledge; and seeing changes in learning through collagues' feedback.

\subsection{The Level of Teachers' Perceptions towards the Effectiveness of Lesson Study}

Chemistry teachers showed positive changes and self-adaptation in the Lesson Study implementation procedures. 
They were followed by English teachers. It turns out that the Chemistry and English teachers were quick to understand the implementation of the procedure and had tried to apply teaching skills to create positive feedback so that its effects could be seen to change students' behavior in the learning process.

The Chemistry teachers gave very positive feedback on the implementation of Lesson Study followed by the English teachers, on average is mostly high, and the reading was above 4.2, while for other subjects was above 4.0, except Bahasa Indonesia.

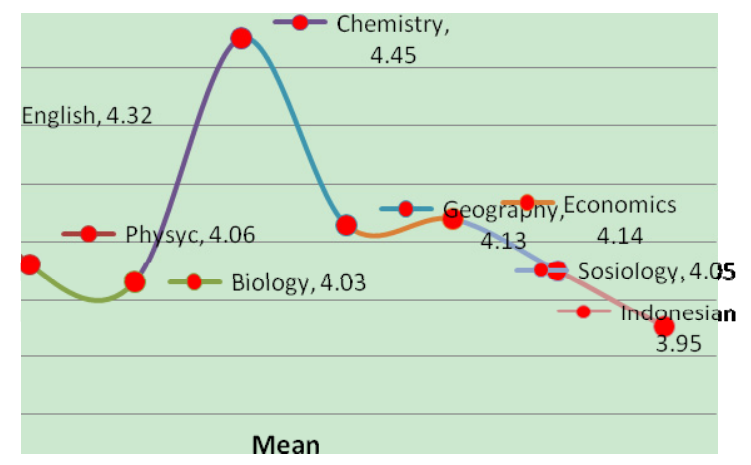

Figure 2. Mean score for teachers' perception on the implementation of Lesson Study to improve the quality of teaching

This lowest level shown by Indonesian language teachers described a relatively low level of readiness in completing lesson materials and preparing for the planning as required are still, as well as an apparent lack of understanding of its implementation. Some Indonesian language teachers were pessimistic about the use of Lesson Study to improve the quality of teaching.

However, it can be concluded that the implementation of Lesson Study in SMA 1 Siak Riau Province had opened the teachers' mind to think in a new way in accepting the new collaborative approach to raise their level of professionalism in teaching through simulation, observation, reflection and actions for improvement.

The teachers agreed that the implementation of Lesson Study is different from the approach in the in-service training which is done in one-way. Lesson Study program has encouraged all subject teachers to work together in finding the best way to improve the quality of their teaching and thus was accepted as a platform to share ideas among themselves in improving their teaching practice.

Table 1 shows the percentage of teachers' acceptance and understanding in implementing and carrying out lessons using Lesson Study approach.

Table 1. Percentage of teachers' acceptance and understanding about lesson study

\begin{tabular}{|c|c|c|c|c|c|}
\hline $\mathrm{N}=40$ & Items & 1 & 2 & 3 & 4 \\
\hline 1. & I understand the concept of LS & & $4(10 \%)$ & $22(55 \%)$ & $14(35 \%)$ \\
\hline 2. & I can apply LS & $1(2.5 \%)$ & $8(20 \%)$ & $28(70 \%)$ & $3(7.5 \%)$ \\
\hline 3. & My teaching is better through LS & $1(2.5)$ & $6(15 \%)$ & $25(62 \%)$ & $8(20 \%)$ \\
\hline 4. & I understand students' character through LS. & $3(7.5 \%)$ & $6(15 \%)$ & $20(50 \%)$ & $11(27 \%)$ \\
\hline 5. & Through my LS can monitor my students. & $2(5 \%)$ & $6(15 \%)$ & $15(37.5 \%)$ & $17(42.5 \%)$ \\
\hline 6. & $\begin{array}{l}\text { I develop better learning strategies through } \\
\text { LS. }\end{array}$ & & $5(12.5 \%)$ & $18(45 \%)$ & $17(42.5 \%)$ \\
\hline 7. & I am more professional through LS. & & $2(5 \%)$ & $22(55 \%)$ & $16(40 \%)$ \\
\hline 8. & My job is so much better through LS & & $1(2.5 \%)$ & $22(55 \%)$ & $17(42.5 \%)$ \\
\hline 9. & Planning is done with quality through LS. & & & $24(60 \%)$ & $16(40 \%)$ \\
\hline
\end{tabular}


10. I work better with colleagues through LS.

$\begin{array}{cccc} & 3(7.5 \%) & 18(45 \%) & 19(47.5 \%) \\ 1(2.5 \%) & 4(10 \%) & 28(70 \%) & 7(17.5 \%) \\ 1(2.5 \%) & 5(12.5 \%) & 24(60 \%) & 10(25 \%) \\ & & & \\ & 4(10 \%) & 22(55 \%) & 14(35 \%) \\ 1(2.5 \%) & 4(10 \%) & 23(57.5 \%) & 12(30 \%) \\ & & & \\ 1(2.5 \%) & 4(10 \%) & 25(62.5 \%) & 10(25 \%) \\ 1(2.5 \%) & 7(17.5 \%) & 30(75 \%) & 2(5 \%) \\ & & & 10(25 \%) \\ 1(2.5 \%) & 7(17.5 \%) & 22(55 \%) & 10(15 \%) \\ & 7(17.5 \%) & 27(67.5 \%) & 6(15 \%) \\ & 1(2.5 \%) & 24(60 \%) & 15(37.5 \%)\end{array}$

11. I can understand the curriculum content well through LS

12. I can enrich the learning materials to suit the students through LS

13. I develop better procedures for learning through LS

14. I take advantage of learning resources better by LS

15. I choose the method that suits the subject title

16. I apply methods that suit the students through LS

17. I am able to help students choose learning resources through LS

18. I can shape students' character through LS

19. I can compile LKS through LS

20. LS application improves the quality of learning.

LS=Lesson Study

Based on the table 1, the level of acceptance for the implementation of Lesson Study teachers is high but they were confident with the positive benefits derived from the implementation of Lesson Study. According to Muzirah Abdul Mokhti \& Nurhana Muhammad Rafiuddin (2013), Lesson Study is able to give a new dimension to teachers about the actual quality of teaching involving various aspects including planning to teach as well as looking at the student's unique learning style.

Overall, Lesson Study was well received by the teachers as a new and innovative approach in developing the professionalism of teachers and was considered beneficial to increase the quality of teaching, because the outcome of collaborative discussions among colleagues has given a lot of input and benefit which gave them practical guidance on the implementation of Lesson Study and provide alternative measures to solve the problem in the context of teaching and learning.

Results from the current study shows that the level of teachers' acceptance of Lesson Study is high, reaching 90\%. A high level of trust indicates teachers' positive perception about the benefits of Lesson Study in improving their teaching skills and quality. Thus, Lesson Study is very suitable to be implemented in school as it does not merely function to provide a platform for observation but also involves the entire process of teacher education assessment including planning, implementation and reflection. This situation will provide benefits and advantages to the students in generating their thinking process.

The results are consistent with the views expressed by Lewis \&Hurd (2011) who regards Lesson Study approach as an innovative method that provides exceptional impact in improving and increasing teachers quality and competencies as the whole team gives many ideas and input for improement. SlametMulyana(2007) has also acknowledged the effectiveness of this method in providing guidance and new ways of educating teachers to overcome their weaknesses and resolve any problems that are encountered in the classroom through constructive criticism from their colleagues who are more competent and experienced.

\subsection{Perception about Lesson Study Program between Students in Different Streams}

Table 2 shows the analysis of teachers' different perceptions on the implementation of Lesson Study using ANOVA test $(\mathrm{F}=.681$ and $\mathrm{Sig}=.687)$.

These data demonstrate the value is greater than alpha sig 00:05, showing that there is no significant distinction in teacher perceptions about the implementation of Lesson Study in improving teachers' qualities of teaching and professionalism in SMA 1, Siak, Riau. 
Table 2. Different perceptions on the implementation of lesson study among science teachers and social science teachers in SMA, Riau, Indonesia

\begin{tabular}{lccccc}
\hline $\mathrm{N}=40$ & Sum of Squares & Df & Mean Square & $\mathrm{F}$ & Sig. \\
\hline Inter-group & .858 & 7 & .123 & .681 & .687 \\
Intra-group & 5.759 & 32 & .180 & & \\
Total & 6.617 & 39 & & & \\
\hline
\end{tabular}

Lewis \& Hurd's (2011) views on the application of Lesson Study as an approach and initiative that is really effective in improving the capacity and professionalism of teachers is also supported by several other researchers such as Brooks \& Brooks (1993) dan Lim Chap Sam. (2003). A possible explanation for the cause of insignificant difference is that the same teacher training were received by the teachers who were not aware of innovative step in the teaching and learning of teachers over the years.

\section{Implications and Recommendations}

Based on the results, it was implied that Lesson Study has had a positive effect on improving the quality of teaching and teacher professionalism. Caska et al. (2011) acknowledge that the Lesson Study should be extended to all levels of schooling. In fact, the findings also show its suitability to be applied in all subjects in science and social science.

The teachers acknowledged that Lesson Study helped them develop educational materials in line with students' needs and is the best approach in shaping students' character. However, the process and implementation requires teachers' willingness to adapt to and adopt the suggestions made in the discussion as a reflection of the implementation of teaching and learning. Margono Slamet (1999) agrees that Lesson Study is a better measure compared to the in-service training to develop teachers' professionalism and to teach more effectively due to guidance and discussion carefully made in a group. This coincides with the results of interviews carried out by Lewis \& Hurd (2011) with a group of teachers in Japan who recognized that Lesson Study is a very effective approach which benefits and provides opportunities for teachers to do the following:

1) Think more carefully about the purpose and specific subject matter to be taught to students.

2) Think about the purposes of teaching for the benefit of future students, for example about the important meaning of friendship, the development of students' perspectives and ways of thinking and the importance of knowledge to the students.

3) Review of the best things that can be used in the teaching based on the outcome of discussions with other teachers.

4) Learn about the subject matter taught by other teachers so that they can gain knowledge about what should be given to the students.

5) Develop teaching skills, both at the time of planning for teaching or teaching activities.

6) Build capacity through collegial teaching, in the sense that teachers can learn from each other about aspects that are perceived to be lacking, both in terms of knowledge or skills to provide meaningful learning experiences..

7) Develop "the eyes to see Students" (kodomowomiru me), the other meaning is that monitoring by observers, on students' learning behavior.

\section{Conclusion}

Lesson Study approach is effective as a means and programs in developing potential and enhancing the professionalism of teachers through collaboration between subject teachers and administrators. Hence, the use is obviously a great benefit to teachers as senior teachers can provide a lot of new ideas to improve the quality of teaching using their experience, while providing a blueprint for the standard form of the ways and steps to be taken by teachers to solve problems in teaching and learning.

\section{References}

Ahmad, A. R., Rahim, A., \& Seman, A. A. (2013). Active learning through History Subject towards Racial Unity in Malaysia. The Social Science, 8(1), 19-24.

Arifin, M. (1995). Development of Teaching Program in Chemistry Studies (Pengembangan Program Pengajaran 
Bidang Studi Kimia). Surabaya: Airlingga University Press.

Awang, M. M., Ahmad, A. R., Wahab, J. L. A., \& Mamat, N. (2013). Effective teaching strategies to encourage learning behaviour. IOSR Journal, 8(2), 35-40.

Awang, M. M., Jindal-Snape, D., \& Barber, T. (2013). A documentary analysis of the government's circulars on positive behaviour enhancement strategies. Asian Social Science, 9(5), 203-208. http://dx.doi.org/10.5539/ass.v9n5p203

Bing, K. W. (2005). Problems in Education (Masalah Pendidikan), Continuing professional development of teachers: human resource development perspective (Perkembangan profesional guru secara berterusan: Perspektif pembangunan sumber manusia). Universiti Malaya, 131.

Brooks, J. G., \& Brooks, M. G. (1993). In search of understanding: The case for constructivist classrooms. Virginia: Association for Supervision and Curriculum Development.

Caska et al. (2011). Mapping and Development of Quality Education in Riau Province (Pemetaan dan Pengembangan Mutu Pendidikan di Provinsi Riau). Research Board of the University of Riau (Lembaga Penelitian Universitas Riau).

Cerbin, B., \& Kopp, B. (n. d.). A Brief Introduction to College Lesson Study. Lesson Study Project. Retrieved from http://www.uwlax.edu/sotl/lsp/index2.htm

Cheah, \& Lim. (2010). Situating Practitioner Research in Future Schools, Edith Cowan University, Australia. National Institute of Education, Nanyang Technological University, Singapore.

Darus, Z. (2012). Status of Student Achievement in TIMSS and PISA: A reflection. Ministry of Education (Status Pencapaian Pelajar dalam TIMSS dan PISA: Satu refleksi. Kementerian Pelajaran Malaysia).

Goldstein, J. (2010). Peer review and teacher leadership. Columbia University, USA : Teacher College Press.

Hayden, M., \& Thompson, J. (2000). International school \& international education. London: Kogan Page Ltd.

Isoda, M., Stephens, M., Ohara, Y., \& Miyakawa, T. (2007). Japanese Lesson Study in Mathematics - Its impact, diversity and potential for education improvement. Singapore: World Scientifics Publishing Co. Ptd Limited.

Kee, K. K., \& Sam, L. C. (2009). Lesson Study: A Potential Driving Force behind the Innovative Use Geometer's Sketchpad. Journal of Mathematics Education, 2(1), 69-82.

Lewis, C. (2002). Does lesson study have a future in the United States. Nagoya Journal of the Education and Human Development, (1), 1-23

Lewis, C., \& Hurd, J. (2011). Lesson Study: Step by step. New York: Heinemann.

Lewis, C., \& Tsuchida, I. (1998). A lesson like a swiftly flowing river: Research lessons and the improvement of Japanese education. American Educator, 22(4).

Makmur, A. S. (2006). Educational Psychology of System tool for Teaching Modules (Psikologi Kependidikan Perangkat Sistem Pengajaran Modul). Bandung: Remaja Rosdakarya.

Mokti, M. A., \& Rafiuddin, N. M. (2013). Perception of science teachers who use Lesson Study as a teacher professional development program for the effectiveness of teaching and learning (Persepsi guru sains yang mengamalkan Lesson Study sebagai program pembangunan profesional guru terhadap keberkesanan pengajaran dan pembelajaran), Proceeding of the Global Summit on Education, 12 March 2013, Kuala Lumpur.

Moore, A. (2004). The Good Teacher: Dominant discourses in teaching and teacher education. London: Routledge Falmer. http://dx.doi.org/10.4324/9780203420270

Moore, K. D. (1999). Instructional Technique. New York: McGraw Hills Book Company.

Mulyana, S. (2007). Lesson Study. Papers (Makalah). Kuningan: LPMP-Jawa Barat.

Orlich, D. C., Harder, J. R., Callahan, J. R., \& Gibson, H. W. (1998). Teaching Strategies: A Guide to Better Instruction. Houghton Mifflin Company, Boston, New York.

Parawansa, P. (2001). Reorientation of the Strategy of National Education. Papers. Presented in the symposium of National Education and the Alumni General Assembly in PPS UM in Malang (Reorientasi terhadap strategi Pendidikan Nasional. Makala. Disajikan dalam simposium Pendidikan Nasional dan Munas I 
alumni PPS UM di Malang), 13 Oktober 2001.

Podhorsky, C., \& Moore, V. (2006). Issues in curriculum: Improving instructional practice through lesson study. Retrieved August 15, 2007, from http://www.lessonstudy.net

Professionalism of Mathematics Teachers and Lecturers. Papers. Presented in the Seminar on Increasing Professionalism of Mathematics Teachers and Lecturers through Lesson Study, in Singaraja (Profesionalisme Guru dan Dosen MIPA. Makalah. Disajikan dalam Seminar Peningkatan Profesionalisme Guru dan Dosen MIPA melalui Lesson Study, di Singaraja), 25 November 2006.

Rhoda, D.B., Yousuf, M. I, Awang, M. M., \& Ranjha, A. N. (2011). The effect of prior knowledge in understanding chemistry concepts by senior secondary school students. International Journal of Academic Research, 3(2), 607-611.

Sam, L. C. (2003). Lesson Study: Enhancing teacher's language proficiency through collaborative processes. ELTC ETeMS Conference 2003: Managing Curricular Change.

Santyasa. (2006). Physics text expansion on conceptual change of model sizes and Community Learning and its effect on student learning outcomes in high school. RUKK Research Report Year II. Research Board of the State IKIP Singaraja (Pengembangan teks fisika bermuatan model perubahan konseptual dan komunitas belajar serta pengaruhnya terhadap perolehan belajar siswa di SMA. Laporan Penelitian RUKK Tahun II. Lembaga Penelitian IKIP Negeri Singaraja).

Senin, A. (2008). Development of Teachers' Professionalism (Pembangunan profesional guru). Jakarta: Rosdakarya.

Siskandar. (2003). Learning technology in a competency based curriculum. Papers. Presented at the national seminar on Learning Technology 22-23 August 2003 at the Inna Garuda Hotel Yogyakarta (Teknologi Pembelajaran dalam kurikulum berbasis kompetensi. Makalah. Disajikan pada seminarnasional Teknologi Pembelajaran pada tanggal22-23 Agustus 2003 di Hotel InnaGaruda Yogyakarta).

Slamet, M. (1999). Quality Learning, Enhancing Quality of Learning Process with Teaching Management Approach (Pembelajaran Bermutu, Peningkatan Mutu Proses Pembelajaran dengan Pendekatan Pengurusan Pengajaran). Depdikbud, Jakarta.

Stepanek, J., Appel, G., Leong, M., Mangan, M. T., \& Mitchell, M. (2007). Leading Lesson Study, A Practical Guide for Teachers and Educators.

Stigler, J. W., \& Hiebert, J. (1999). The Teaching Gap: Best ideas from the worlds teachers for improving education in classroom. New York: Free Press.

Susilo, H. (2007). What and Why Lesson Study Should Do to Improve Mathematics Teachers and Lecturers Professionalism. Papers. Served in the Seminar on Enhancing Professionalism of Teachers and Lecturers MIPA through Lesson Study, in Singaraja, 25 November 2006. (Apa dan Mengapa Lesson Study Perlu Dilakukan untuk Meningkatkan Profesionalisme Guru dan Dosen MIPA. Makalah. Disajikan dalam Seminar Peningkatan Profesionalisme Guru dan Dosen MIPA melalui Lesson Study, di Singaraja, 25 November 2006.)

Sutopo, \& Ibrahim. (2006). Experience in the Implementation of Lesson Study IMSTEP. Papers. served in Seminar on Training partnership between Institutes-Schools in order to improve the quality of Mathematics and Natural Sciences Education, at the Hotel Yogyakarta, 27-29 July, 2006. (Pengalaman IMSTEP dalam Implementasi Lesson Study. Makalah. Disajikan dalam Pelatihan kemitraan LPTK-Sekolah dalam rangka peningkatan mutu Pendidikan MIPA, di Hotel Yogyakarta, 27-29 Juli 2006.)

Suyanto. (2001). National Education formula in the global era. Papers. Served in the National Educational Symposium and General Assembly I alumni PPS.UM. in Malang, October 13, 2001. (Formula Pendidikan Nasional era global. Makalah. Disajikan dalam simposium Pendidikan Nasional dan munas I alumni PPS.UM. di Malang, 13 Oktober 2001).

Wang-Iverson, P. (2002). Why Lesson Study. Retrieved from http://www.rbs.org/lesson_study-/confenrence/2002/paper/wang.shtml

Wikipedia. (2007). Lesson Study. Retrieved from http://en.wikipedia.org/wiki/Lesson_study

Yoshida, M. (1999). Lesson Study: A case study of a Japanese approach to improving instruction through school based teacher development. Japan. 


\section{Copyrights}

Copyright for this article is retained by the author(s), with first publication rights granted to the journal.

This is an open-access article distributed under the terms and conditions of the Creative Commons Attribution license (http://creativecommons.org/licenses/by/3.0/). 